\title{
Retraction Note to: Inhibition of microRNA miR-92a induces apoptosis and inhibits cell proliferation in human acute promyelocytic leukemia through modulation of $\mathrm{p} 63$ expression
}

\author{
Mohammadreza Sharifi $^{1} \cdot$ Rasoul Salehi $^{1} \cdot$ Yousof Gheisari $^{1} \cdot$ Mohammad Kazemi $^{1}$
}

Published online: 6 August 2019

(c) Springer Nature B.V. 2019

\section{Retraction Note to: \\ Molecular Biology Reports (2014) 41:2799-2808 \\ https://doi.org/10.1007/s11033-014-3134-5}

The Editor-in-Chief has decided to retract this article [1]. The article shows significant overlap with two prior publications by the same authors [2, 3], without providing the due citation and attribution.

\section{References}

1. Sharifi M, Salehi R, Gheisari Y et al (2014) Inhibition of microRNA miR-92a induces apoptosis and inhibits cell proliferation in human acute promyelocytic leukemia through modulation of p63 expression. Mol Biol Rep 41:2799. https://doi.org/10.1007/s1103 3-014-3134-5

2. Sharifi M, Salehi R, Gheisari $Y$ et al (2013) Inhibition of microRNA miR-92a inhibits cellproliferation in human acute promyelocytic leukemia. Turk J Hematol 30:157-162. https://doi. org/10.4274/Tjh.2012.0171

3. Sharifi M, Salehi R, Gheisari Y et al (2014) Inhibition of microRNA miR-92a induces apoptosis and necrosis in human acute promyelocytic leukemia. Adv Biomed Res 3(1):61. https://doi. org/10.4103/2277-9175.125826

Publisher's Note Springer Nature remains neutral with regard to jurisdictional claims in published maps and institutional affiliations.

The original article can be found online at https://doi.org/10.1007/ s11033-014-3134-5.

Rasoul Salehi

r_salehi@med.mui.ac.ir

1 Department of Genetics and Molecular Biology, School of Medicine, Isfahan University of Medical Sciences, 81744-176 Isfahan, Iran 